The Chittagong Univ. J. B. Sci., Vol. 4(1 \&2):107-117, 2009.

\title{
CHARACTERIZATION OF MICROORGANISMS FROM SITAKUNDA HOT SPRING
}

\author{
M.Z. HOSSAIN AND M.N ANWAR ${ }^{1}$ \\ Department of Microbiology, University of Chittagong, Chittagong-4331, Bangladesh
}

\begin{abstract}
Water, leaf, stone and sand samples from Sitakunda hot spring were studied and the microorganisms isolated from these samples were thoroughly characterized. The $\mathrm{pH}$ of the collected samples was found to range from 8.5 to 8.9 and the recorded temperature varied from 26.1 to $29.8{ }^{\circ} \mathrm{C}$ during winter season. BOD of the collected water samples ranged from 10 to $92 \mathrm{mg} / \mathrm{L}$, while COD was almost zero. The total alkalinity and chlorine content ranged from 12 to $20 \mathrm{mg} / \mathrm{L}$ and 13.9 to $18.3 \mathrm{gm} / \mathrm{L}$ respectively. Quantitative enumeration of bacterial population showed the range of $8.0 \times 10^{2}$ to $3.8 \times 10^{5} \mathrm{cfu} / \mathrm{ml}$ or gm sample. All the 9 selected isolates were identified as Bacillus coagulans $\left(\mathrm{S}_{1} \mathrm{~B}_{4}\right)$, Bacillus laterosporus $\left(\mathrm{SB}_{18}\right)$, Bacillus megaterium $\left(\mathrm{S}_{2} \mathrm{~B}_{11}\right)$, Bacillus popilliae $\left(\mathrm{S}_{4} \mathrm{P}_{1}\right)$, Bacillus firmus $\left(\mathrm{S}_{5} \mathrm{~B}_{1}\right)$, Citrobacter intermedius $\left(\mathrm{S}_{4} \mathrm{~B}_{17}\right)$, Listeria monocytogenes $\left(\mathrm{S}_{1} \mathrm{~B}_{1}\right)$, Listeria denitrificans $\left(\mathrm{S}_{2} \mathrm{~B}\right)$ and Pseudomonas mendocina $\left(\mathrm{S}_{4} \mathrm{P}_{3}\right)$. Bacillus laterosporus, Bacillus megaterium and Listeria denitrificans showed better growth in presence of methane gas in nutrient broth. By direct microscopic observation 7 genera of cyanobacteria (Arthrospria, Microcoleus, Oscillatoria, Schyzothrix, Scytonema, Nostoc and Gloeocapsa) and 4 genera of diatoms (Gomphonema, Melosira, Navicula and Pinnularia) were detected in the water sample.
\end{abstract}

Key words: Characterization, Microbe, Hot spring.

\section{INTRODUCTION}

Little was known about how microbes live their lives in hot spring. Mainly thermophiles are found in hot spring and among them Archaea and Cyanobacteria are common (Encyclopedia of Environmental Microbiology 2002. vol.3). Brock (1966) made the remarkable discovery that microorganisms were growing in the boiling hot springs of Yellowstone National Park Since Brock's discovery, thermopiles have been discovered in geothermal features all over the world including areas in Iceland, Kamchatka, New Zealand, Italy, Mt. Lassen, and other locations. Microorganisms other than Sulfolobus are reported for the first time in

Corresponding author : E-mail: anwarmn51@yahoo.com. 
HOSSAIN AND ANWAR.

the low $\mathrm{pH}$ high temperature springs of Waiotapu, North Island, New Zealand (Ellis et al. 2005). The bacterial diversity of a hot spring in Bakreshwar, India, was investigated by a culture-independent approach (Ghosh et al. 2003). A halophilhic, thermotolerant Bacillus strain (B3-15) was isolated from water of a shallow, marine hot spring at Vulcano Island (Eolian Islands, Italy). From 16S rDNA analysis, strain B3-15 was related to B. licheniformis (Teresa et al. 2002). A thermophilic bacterium Bacillus sp. strain TB-1 was isolated in association with the yeast Debaryomyces vanriji from hot springs at $46^{\circ} \mathrm{C}$ (Eugene et al. 1999). A polyphasic taxonomic study was performed on a novel facultatively anaerobic, hydrogen- or sulfur/thiosulfate-oxidizing, thermophilic chemolithoautotroph recently isolated from subsurface hot aquifer water in a Japanese gold mine (Takai et al. 2003).Laminatd mats of unique character in siliceous alkaline hot springs of Yellowstone Park are formed predominantly by two organisms, a unicellular blue green alga, Synechococcus lividus, and a filamentous,gliding,photosynthetic bacterium, Chloroflexus aurantiacus (Doemel and Brock 1977)

Sitakunda Hot Spring is the only hot spring in Bangladesh. It is located at Barobkunda, Sitakunda, Chittagong. Still no work has been done on this hot spring. This spring mainly consists of two rectangular wells. In one well, methane gas and water are continuously discharging from the ground to the surface. Fire can be burnt on the surface of water and it would be continued for long time, even never switched off spontaneously, because of the continuous flow of methane gas. From this well water flows to another well that receives no flow of methane gas. The present work was undertaken to study the micro flora associated with this hot spring.

\section{MATERIALS AND METHODS}

Samples were collected from different parts of the hot springs in cleaned, dried and surface sterilized (with $70 \%$ alcohol) plastic bottles and polyethylene bags. The solid samples were taken in the polyethylene bags while liquid samples were taken in plastic bottles. At each time of collection, hands were sterilized with $70 \%$ alcohol. Temperature in the field was measured with a maximum recording mercury thermometer. $\mathrm{pH}$ of each of the samples was determined by the electric $\mathrm{pH}$ meter ( $\mathrm{pH}$ Hanna Instrument Ltd. \& 3310, pH meter Jenway, UK).

After collection, samples were brought to the laboratory and carefully preserved in the refrigerator at $4^{\circ} \mathrm{C}$ before and after the microbial analysis. BOD, 


\section{MICROORGANISMS FROM HOT SPRING}

COD, total alkalinity and Chlorine content of the collected samples were determined.

For the enumeration and isolation of bacteria, serial dilution was carried out up to $10^{6}$ dilutions. Plating in triplicate plates was made for each dilute sample either by Pour Plate Technique or by Spread Plate Technique using Nutrient agar as the medium. The plates were incubated at $37^{\circ} \mathrm{C}$ in an incubator for 24 to 48 hours. After incubation, well-spaced plates were placed on a colony counter (Stuart scientific, UK) and the colonies were counted. . Characters of the colonies were recorded as colour, form, elevation, margin, surface etc. (Eklund and Lankford 1967, Bryan 1950). The marked and observed colonies were transferred on nutrient agar slant for purification. Morphological, physiological and biochemical characteristics of the isolates were recorded.

In order to study the utility of methane gas by the selected isolates, methane gas was aseptically introduced into Nutrient broth and Inorganic Salt media and was inoculated with 72 hour old cultures.

Collected samples were observed directly under microscope for Cyanobacteria and diatoms using 10x, 40x, 60x and 100x objectives.

\section{RESULTS AND DISCUSSION}

Table-1 presents the features of the samples collected from different parts of the spring and of the microbial populations of each sample.

The temperature of the spring ranged from 26.1 to $29.8^{0} \mathrm{C}$ during winter season and $\mathrm{pH}$ from 8.5 to 8.9. BOD of the collected samples from both wells of the hot spring was also determined within one hour of the collection. The BOD of the methane containing well was found $10 \mathrm{mg} / \mathrm{L}$ while BOD of other well was found $92 \mathrm{mg} / \mathrm{L}$. The reason of higher BOD in the second well was the growth of different types of algae, cyanobacteria, arthropods etc., which were not found in the first well. COD of the collected samples was found almost zero or very poor. The reasons of this result may be the unusual conditions of the hot spring. 
HOSSAIN AND ANWAR.

TABLE-1: FEATURES OF THE SAMPLES COLLECTED FROM DIFFERENT PARTS OF THE SPRING.

\begin{tabular}{|c|c|c|c|c|c|c|}
\hline $\begin{array}{l}\text { Collected } \\
\text { samples }\end{array}$ & Colour & $\begin{array}{l}\text { Temp. } \\
\left({ }^{0} \mathrm{C}\right)\end{array}$ & $\mathrm{pH}$ & $\begin{array}{l}\text { Total } \\
\text { alkalinity } \\
(\mathrm{mg} / \mathrm{L})\end{array}$ & $\begin{array}{l}\text { Chlorine } \\
\text { content } \\
(\mathrm{gm} / \mathrm{L})\end{array}$ & $\begin{array}{l}\text { Total } \\
\text { bacterial } \\
\text { count * }\end{array}$ \\
\hline $\begin{array}{l}\text { Water from the } \\
\text { well with } \\
\text { methane and } \\
\text { water } \\
\text { discharging }\end{array}$ & Colourless & 29.8 & 8.8 & 12 & 13.9 & $8.0 \times 10^{2}$ \\
\hline $\begin{array}{l}\text { Water from the } \\
\text { well without } \\
\text { methane and } \\
\text { water } \\
\text { discharging }\end{array}$ & Colourless & 26.7 & 8.9 & 19 & 18.3 & $1.3 \times 10^{3}$ \\
\hline $\begin{array}{l}\text { Water from the } \\
\text { well without } \\
\text { methane and } \\
\text { water } \\
\text { discharging }\end{array}$ & $\begin{array}{l}\text { Light } \\
\text { green }\end{array}$ & 26.1 & 8.5 & 20 & 17.4 & $6.2 \times 10^{4}$ \\
\hline $\begin{array}{l}\text { Leaves, stones, } \\
\text { sands etc. from } \\
\text { the well without } \\
\text { methane and } \\
\text { water } \\
\text { discharging }\end{array}$ & $\begin{array}{l}\text { Black, } \\
\text { green }\end{array}$ & 26.1 & 8.8 & 17 & 18.1 & $3.8 \times 10^{5}$ \\
\hline $\begin{array}{l}\text { Leaves, stones, } \\
\text { sands etc. from } \\
\text { the well with } \\
\text { methane and } \\
\text { water } \\
\text { discharging }\end{array}$ & $\begin{array}{l}\text { Black, } \\
\text { white }\end{array}$ & 29.8 & 8.7 & 14 & 15.2 & $2.5 \times 10^{3}$ \\
\hline
\end{tabular}




\section{MICROORGANISMS FROM HOT SPRING}

Different cultural (Table- 2), morphological and staining features of finally selected 9 isolates (Table- 3) were recorded. Among the colony types, circular type colony was found to be dominant type.

TABLE- 2: COLONY CHARACTERISTICS OF THE SELECTED ISOLATES ON NUTRIENT AGAR .

\begin{tabular}{lllllll}
\hline Isolate & Color & Form & Elevation & Margin & Surface & $\begin{array}{l}\text { Slant } \\
\text { character }\end{array}$ \\
\hline $\mathrm{S}_{1} \mathrm{~B}_{1}$ & Translucent & Circular & Flat & Entire & Smooth & Filiform \\
$\mathrm{S}_{1} \mathrm{~B}_{4}$ & Translucent & Punctiform & Flat & Entire & Smooth & Filiform \\
$\mathrm{S}_{1} \mathrm{~B}_{18}$ & Milk white & Punctiform & Flat & Entire & Smooth & Filiform \\
$\mathrm{S}_{2} \mathrm{~B}_{5}$ & Cream & Circular & Raised & Entire & Smooth & Echinulate \\
$\mathrm{S}_{2} \mathrm{~B}_{11}$ & White & Circular & Flat & Erose & Contoured & Echinulate \\
$\mathrm{S}_{4} \mathrm{P}_{1}$ & Cream & Circular & Flat & Entire & Smooth & Filiform \\
$\mathrm{S}_{4} \mathrm{P}_{3}$ & Light & Circular & Flat & Entire & Smooth & Filiform \\
& Yellow & & & & & \\
$\mathrm{S}_{4} \mathrm{~B}_{17}$ & Milk white & Circular & Raised & Entire & Smooth & Filiform \\
$\mathrm{S}_{5} \mathrm{~B}_{1}$ & White & Filamentous & Flat & Filamentous & Smooth & Arborescent \\
\hline
\end{tabular}

Of 9 isolates, 8 were short rods and only 1 isolate $\left(S_{1} B_{18}\right)$ was long rod. No cocci were found in the selected isolates. The isolates were also different in their arrangement of cells. Grams staining of the selected isolates revealed that majority of them were gram positive while only 3 of them were gram negative. Acid fast staining of the isolates showed that all of them were non-acid fast. Among 9 isolates, 5 were spore formers and 4 were non-spore formers (Table- 3 ). Spores were round to cylindrical and central.

The morphological, physiological and biochemical features are shown inTable- $3 \& 4$. All the 9 isolates were found to belong to 4 genera (Bacillus, Citrobacter, Listeria, and Pseudomonas). Among these genera, Bacillus and Pseudomonas genera were reported from different hot spring by different workers (Belly and Brock 2008). The reason of finding of Listeria in study may be due to 
HOSSAIN AND ANWAR.

the presence of leaf litter in the spring (Buchanan and Gibbons 1974). The isolates were provisionally identified as Bacillus coagulans $\left(\mathrm{S}_{1} \mathrm{~B}_{4}\right)$, Bacillus laterosporus $\left(\mathrm{SB}_{18}\right)$, Bacillus megaterium $\left(\mathrm{S}_{2} \mathrm{~B}_{11}\right)$, Bacillus popilliae $\left(\mathrm{S}_{4} \mathrm{P}_{1}\right)$, Bacillus firmus, $\left(\mathrm{S}_{5} \mathrm{~B}_{1}\right)$, Citrobacter intermedius $\left(\mathrm{S}_{4} \mathrm{~B}_{17}\right)$, Listeria monocytogenes $\left(\mathrm{S}_{1} \mathrm{~B}_{1}\right)$, Listeria denitrificans $\left(\mathrm{S}_{2} \mathrm{~B}_{5}\right)$ and Pseudomonas mendocina $\left(\mathrm{S}_{4} \mathrm{P}_{3}\right)$, by comparing with the standard description of "Bergey's Manual of Determinative Bacteriology" 8 th $\mathrm{ed}$. (Buchanan and Gibbons 1974).

TABLE-3: MICROSCOPIC FEATURES OF THE SELECTED ISOLATES

\begin{tabular}{|c|c|c|c|c|c|}
\hline Isolates & Form & Arrangement & $\begin{array}{l}\text { Gram } \\
\text { reaction }\end{array}$ & $\begin{array}{l}\text { Acid fast } \\
\text { staining }\end{array}$ & $\begin{array}{l}\text { Spore } \\
\text { staining }\end{array}$ \\
\hline $\mathrm{S}_{1} \mathrm{~B}_{1}$ & Short rod & $\begin{array}{l}\text { Single, pair } \\
\text { and cluster }\end{array}$ & $\begin{array}{l}\text { Gram } \\
\text { positive }\end{array}$ & $\begin{array}{l}\text { Non acid } \\
\text { fast }\end{array}$ & $\begin{array}{l}\text { Non spore } \\
\text { former }\end{array}$ \\
\hline $\mathrm{S}_{1} \mathrm{~B}_{4}$ & Short rod & $\begin{array}{l}\text { Single, pair } \\
\text { and cluster }\end{array}$ & $\begin{array}{l}\text { Gram } \\
\text { positive }\end{array}$ & $\begin{array}{l}\text { Non acid } \\
\text { fast }\end{array}$ & $\begin{array}{l}\text { Spore } \\
\text { former }\end{array}$ \\
\hline $\mathrm{S}_{1} \mathrm{~B}_{18}$ & Long rod & $\begin{array}{l}\text { Single and } \\
\text { pair }\end{array}$ & $\begin{array}{l}\text { Gram } \\
\text { positive }\end{array}$ & $\begin{array}{l}\text { Non acid } \\
\text { fast }\end{array}$ & $\begin{array}{l}\text { Spore } \\
\text { former }\end{array}$ \\
\hline $\mathrm{S}_{2} \mathrm{~B}_{5}$ & Short rod & $\begin{array}{l}\text { Single and } \\
\text { short chain }\end{array}$ & $\begin{array}{l}\text { Gram } \\
\text { positive }\end{array}$ & $\begin{array}{l}\text { Non acid } \\
\text { fast }\end{array}$ & $\begin{array}{l}\text { Non spore } \\
\text { former }\end{array}$ \\
\hline $\mathrm{S}_{2} \mathrm{~B}_{11}$ & Short rod & $\begin{array}{l}\text { Single, pair } \\
\text { and chain }\end{array}$ & $\begin{array}{l}\text { Gram } \\
\text { positive }\end{array}$ & $\begin{array}{l}\text { Non acid } \\
\text { fast }\end{array}$ & $\begin{array}{l}\text { Spore } \\
\text { former }\end{array}$ \\
\hline $\mathrm{S}_{4} \mathrm{P}_{1}$ & Short rod & $\begin{array}{l}\text { Single, pair } \\
\text { and chain }\end{array}$ & $\begin{array}{l}\text { Gram } \\
\text { positive }\end{array}$ & $\begin{array}{l}\text { Non acid } \\
\text { fast }\end{array}$ & $\begin{array}{l}\text { Spore } \\
\text { former }\end{array}$ \\
\hline $\mathrm{S}_{4} \mathrm{P}_{3}$ & Short rod & $\begin{array}{l}\text { Single and } \\
\text { pair }\end{array}$ & $\begin{array}{l}\text { Gram } \\
\text { negative }\end{array}$ & $\begin{array}{l}\text { Non acid } \\
\text { fast }\end{array}$ & $\begin{array}{l}\text { Non spore } \\
\text { former }\end{array}$ \\
\hline $\mathrm{S}_{4} \mathrm{~B}_{17}$ & Short rod & $\begin{array}{l}\text { Single and } \\
\text { pair }\end{array}$ & $\begin{array}{l}\text { Gram } \\
\text { negative }\end{array}$ & $\begin{array}{l}\text { Non acid } \\
\text { fast }\end{array}$ & $\begin{array}{l}\text { Non spore } \\
\text { former }\end{array}$ \\
\hline $\mathrm{S}_{5} \mathrm{~B}_{1}$ & Short rod & $\begin{array}{l}\text { Single, pair } \\
\text { and chain }\end{array}$ & $\begin{array}{l}\text { Gram } \\
\text { positive }\end{array}$ & $\begin{array}{l}\text { Non acid } \\
\text { fast }\end{array}$ & $\begin{array}{l}\text { Spore } \\
\text { former }\end{array}$ \\
\hline
\end{tabular}




\section{MICROORGANISMS FROM HOT SPRING}

Natural methane gas was aseptically diffused in the Nutrient broth and in the Inorganic salt media of screw-capped test tubes. Control without methane gas was also maintained in every case. Selected isolates were inoculated separately in the media and incubated at $37^{\circ} \mathrm{C}$. The isolate $\mathrm{S}_{1} \mathrm{~B}_{18}, \mathrm{~S}_{2} \mathrm{~B}_{5}$ and $\mathrm{S}_{2} \mathrm{~B}_{11}$ showed enhanced growth in Nutrient broth. Again, isolate $S_{1} B_{18}$ and $S_{2} B_{11}$ showed trace growth in natural gas containing Inorganic salt medium, which showed no growth in this medium in the absence of natural gas (Table- 5).

In the present study, samples were also directly observed under microscope. The samples collected from outer well was found to have cyanobacteria and diatoms. The observed genera were compared with the standard descriptions illustrated in different books (Sharma 1986, Vashishta 1999, Bold and Wynne 1985). Seven genera of cyanobacteria and 4 genera of Bacillariophyceae were identified. The identified genera of cyanobacteria were Gloeocapsa, Arthrospira, Oscillatoria, Microcoleus, Nostoc, Scytonema and Scyzothrix. Among these genera, Arthrospira, Oscillatoria and Scytonema were very common (Table- 6). Similar genera were reported by various workers from different hot springs [Oscillatoria (Castenholz 1967), Gloeocapsa (Bonny and Jones 2003), Arthrospira (Walter et al, 2006) and Scytonema (Rezanka et al 2003)]. The identified genera of Bacillariophyceae were Gomphonema, Melosira, Navicula and Pinnularia (Table- 7). 
HOSSAIN AND ANWAR.

TABLE 4: BIOCHEMICAL AND PHYSIOLOGICAL CHARACTERISTICS OF THE SELECTED ISOLATES.

\begin{tabular}{|c|c|c|c|c|c|c|c|c|c|}
\hline Characteristic & $\mathrm{S}_{1} \mathrm{~B}_{1}$ & $\mathrm{~S}_{1} \mathrm{~B}_{4}$ & $\mathrm{~S}_{1} \mathrm{~B}_{18}$ & $\mathrm{~S}_{2} \mathrm{~B}_{5}$ & $\mathrm{~S}_{2} \mathrm{~B}_{11}$ & $\mathrm{~S}_{4} \mathrm{P}_{1}$ & $\mathrm{~S}_{4} \mathrm{P}_{3}$ & $\mathrm{~S}_{4} \mathrm{~B}_{17}$ & $\mathrm{~S}_{5} \mathrm{~B}_{1}$ \\
\hline Catalase test & + & + & + & + & + & + & + & + & + \\
\hline Casein hydrolysis & - & + & - & + & + & - & - & + & - \\
\hline Starch hydrolysis & - & - & - & + & + & - & - & + & - \\
\hline Gelatin hydrolysis & - & + & + & + & + & - & - & + & + \\
\hline Nitrate reduction & - & - & \pm & \pm & + & - & + & + & + \\
\hline Deep glucose agar test & A & $\mathrm{F}$ & $\mathrm{A} / \mathrm{F}$ & $\mathrm{A} / \mathrm{F}$ & $\mathrm{A} / \mathrm{F}$ & A & $\mathrm{A} / \mathrm{F}$ & $\mathrm{A} / \mathrm{F}$ & $\mathrm{A} / \mathrm{F}$ \\
\hline Proteolysis & - & - & - & - & - & - & - & - & - \\
\hline $\mathrm{H}_{2} \mathrm{~S}$ Production & - & - & - & \pm & - & - & - & - & - \\
\hline Oxidase test & - & - & - & - & - & - & + & - & - \\
\hline Indole test & - & - & - & - & - & - & - & + & - \\
\hline Methyle Red test & - & - & - & - & - & - & - & - & + \\
\hline Voges Proskauer test & - & - & - & - & - & - & - & - & - \\
\hline Citrate test & + & + & + & + & \pm & - & + & + & \pm \\
\hline Urease test & + & + & + & - & \pm & + & + & + & - \\
\hline Motility & \pm & + & \pm & + & + & \pm & + & + & + \\
\hline Growth at $\mathrm{pH} 4.5$ & + & ++ & \pm & + & \pm & + & \pm & + & ++ \\
\hline Growth at $\mathrm{pH} 8.5$ & +++ & +++ & ++ & +++ & +++ & +++ & +++ & +++ & +++ \\
\hline Heat tolerance at $60^{\circ} \mathrm{C}$ & + & + & +++ & +++ & +++ & +++ & + & + & +++ \\
\hline $\begin{array}{l}\text { Maximum salt } \\
\text { tolerance }\end{array}$ & $3 \%$ & $3 \%$ & $3 \%$ & $12 \%$ & $4 \%$ & $6 \%$ & $2 \%$ & $2 \%$ & $2 \%$ \\
\hline Glucose fertmentation & $\begin{array}{l}\text { Alk- } \\
\text { ali }\end{array}$ & Acid & $\begin{array}{l}\text { Alk- } \\
\text { ali }\end{array}$ & $\begin{array}{l}\text { Alk- } \\
\text { ali }\end{array}$ & Acid & Acid & Acid & Acid & Acid \\
\hline Lactose fermentation & $\begin{array}{l}\text { Alk- } \\
\text { ali }\end{array}$ & $\begin{array}{l}\text { Alk- } \\
\text { ali }\end{array}$ & $\begin{array}{l}\text { Alk- } \\
\text { ali }\end{array}$ & $\begin{array}{l}\text { Alk- } \\
\text { ali }\end{array}$ & $\begin{array}{l}\text { Alk- } \\
\text { ali }\end{array}$ & $\begin{array}{l}\text { Alk- } \\
\text { ali }\end{array}$ & $\begin{array}{l}\text { Alk- } \\
\text { ali }\end{array}$ & $\begin{array}{l}\text { Alk- } \\
\text { ali }\end{array}$ & Acid \\
\hline
\end{tabular}

Note: $\mathrm{A}=$ Aerobic, $\mathrm{F}=$ Facultative,$+=$ Positive,$-=$ Negative,$\pm=$ Variable 
MICROORGANISMS FROM HOT SPRING

TABLE-5: DIFFERENCES BETWEEN THE GROWTH IN THE MEDIA WITH OR WITHOUT METHANE GAS.

\begin{tabular}{lcccc}
\hline & Nutrient & Broth & Inorganic & Salt \\
\cline { 2 - 5 } Isolates & without $\mathrm{CH}_{4}$ & With $\mathrm{CH}_{4}$ & without $\mathrm{CH}_{4}$ & with $\mathrm{CH}_{4}$ \\
\hline $\mathrm{S}_{1} \mathrm{~B}_{1}$ & +++ & +++ & - & - \\
$\mathrm{S}_{1} \mathrm{~B}_{4}$ & +++ & +++ & - & - \\
$\mathrm{S}_{1} \mathrm{~B}_{18}$ & ++ & +++ & - & Trace \\
$\mathrm{S}_{2} \mathrm{~B}_{5}$ & ++ & +++ & - & - \\
$\mathrm{S}_{2} \mathrm{~B}_{11}$ & + & +++ & - & Trace \\
$\mathrm{S}_{4} \mathrm{P}_{1}$ & ++ & ++ & - & - \\
$\mathrm{S}_{4} \mathrm{P}_{3}$ & ++ & ++ & - & - \\
$\mathrm{S}_{4} \mathrm{~B}_{17}$ & +++ & +++ & - & - \\
$\mathrm{S}_{5} \mathrm{~B}_{1}$ & ++ & +++ & - & - \\
\hline
\end{tabular}

Note: $+=$ Positive $(+=$ Scanty, $++=$ Moderate,$+++=$ Heavy $),-=$ Negative.

TABLE-6: FEATURES OF THE IDENTIFIED GENERA OF CYANOBACTERIA.

\begin{tabular}{|c|c|c|}
\hline $\begin{array}{l}\text { Name of the } \\
\text { family }\end{array}$ & Name of the genera & Description \\
\hline Chroococcaceae & Gloeocapsa & $\begin{array}{l}\text { Subaerial, palmelloid, colonies were in gelatinous } \\
\text { masses, cells were more or less spherical. }\end{array}$ \\
\hline \multirow[t]{4}{*}{ Oscillatoriaceae } & Arthrospira & $\begin{array}{l}\text { Filamentous. closely spiral, trichomes are enclosed } \\
\text { with mucilaginous sheath, brown to blue green colour. }\end{array}$ \\
\hline & Oscillatoria & $\begin{array}{l}\text { Long filamentous, filaments were naked; trichomes } \\
\text { were cylindrical and unbranched, dark blue green } \\
\text { colour. }\end{array}$ \\
\hline & Microcoleus & $\begin{array}{l}\text { Filamentous, more than one trichomes, trichomes are } \\
\text { enclosed with mucilaginous sheath, blue green colour. }\end{array}$ \\
\hline & Scyzothrix & $\begin{array}{l}\text { Filamentous, single trichome was observed, yellowish } \\
\text { green in colour. }\end{array}$ \\
\hline Scytonemataceae & Scytonema & $\begin{array}{l}\text { Filamentous, trichomes were enclosed with } \\
\text { mucilaginous seath like bundles, single filament was } \\
\text { also enclosed with sheath, false branching occurred, } \\
\text { blue green colour. }\end{array}$ \\
\hline Nostocaceae & Nostoc & $\begin{array}{l}\text { Germinating hormogonia was observed, trichomes } \\
\text { were enclosed with gelatinous matrix, blue green } \\
\text { colour. }\end{array}$ \\
\hline
\end{tabular}


HOSSAIN AND ANWAR.

TABLE-7: FEATURES OF THE IDENTIFIED GENERA OF BACILLARIOPHYCEAE.

\begin{tabular}{ll}
\hline Genus & \multicolumn{1}{c}{ Description } \\
\hline Gomphonema & $\begin{array}{l}\text { Cell was golden to brown, one end was narrow and } \\
\text { another end was broad and blunt, one polar nodule } \\
\text { was present in each end. } \\
\text { Thelosira }\end{array}$ \\
$\begin{array}{l}\text { Thee distinct cells were present; cells were } \\
\text { rectangular, long and sometimes coiled } \\
\text { filamentouss, green colour. }\end{array}$ \\
Navicula & $\begin{array}{l}\text { Two ends of the cells were tapping, attenuated with } \\
\text { round apics; raphe was axile, distinct, straight with } \\
\text { small polar and central nodule; golden brown cell } \\
\text { wall. }\end{array}$ \\
& $\begin{array}{l}\text { Two ends of the cells were equally thick, not } \\
\text { attenuated, contain nodule in each end. }\end{array}$
\end{tabular}

\section{REFERENCES}

BELLY, R. T. AND BROCK, T. D. 2008. Widespread Occurrence of Acidophilic Strains of Bacillus coagulans in Hot Springs. Journal of Applied Microbiol. 37(1): 175 - 177.

BOLD, C.H. AND WYNNE, M.J. 1985. An Introduction to the Algae, $2^{\text {nd }}$ ed. Prentic Hall. pp.1-720

BONNY, S. AND JONES, B. 2003. Microbes and mineral precipitation, Miette Hot Springs, Jasper National Park, Alberta, Canada. Canadian Journal of Earth Sciences. 11(1): 1483-1500

BROCK,T.1966.Cited from "Microbial Life" described in http.//serc.carleton.eau/microbelife/extreme heat/index.html

BRYAN, H. 1950. Manual of methods for pure culture study of Bacteria. 12 (1) : Leaflet I-X. Megraw Hill Book Co. Inc. New York.

BUCHANAN, R. E. GIBBONS, N. E. 1974. Bergey's Manual of Determinative Bacteriology. The William and Wilkins Co. Baltimore. pp.1268

CASTENHOLZ, R.W. 1967. Aggregation in a Thermophilic Oscillatoria. Nature. 215: $1285-1286$. 
MICROORGANISMS FROM HOT SPRING

DOEMEL, W. N. AND BROCK, D.T. 1977. Structure, Growth, and Decomposition of Laminated Algal-Bacterial Mats in Alkaline Hot Springs. Appl Environt. Microbiol. 34(4): 433-452.

EKLUND, C. AND LANKFORD 1967. Laboratory Manual for General Microbiology Prentice-Hall, Inc., Englewood Cliffs, New Jersey. pp: 1551.

ELLIS, D. G., RICHARD L., BIZZOCO, W., MAEZATO, Y., JUDITH, N., BAGGETT, AND SCOTT, T. K. 2005. Microscopic examination of acidic hot springs of Waiotapu,North Island, New Zealand. New Zealand Journal of Marine and Freshwater Research. 39: 1001-1011.

EUGENE, G. R., NINA, N., DMITRI, V., SOZINOV, Y. AND VIKTOR, K. V. 1999. Association of Bacteria and Yeasts in Hot Springs. Appl. Environt. Microbiol. 65(9): 4292-4293.

GHOSH, D., BAL, B. V. K. AND PAL, K.S. 2003. Molecular Phylogenetic Exploration of Bacterial Diversity in a Bakreshwar (India) Hot Spring and Culture of Shewanella-Related Thermophiles. Applied and Environmental Microbiol. 69(7): 4332-4336.

REZANKA, T., DEMBITSKY, V.M., PRELL, A. AND HANUS, L. 2003. Sterol composition of the filamentous nitrogen- fixing terrestrial Cyanobacterium, Scytonema sp. Folia Microbiol. 48(3): 357-360.

SHARMA, O.P. 1986. A Text Book of Algae. Tata McGraw-Hill Pub. Co. Ltd. New Delhi. pp.1-396

TAKAI, K., KOBAYASHI, H., KENNETH, H. AND KOKI, N. H. 2003. Sulfurihydrogenibium subterraneum gen. nov., sp. nov., from a subsurface hot aquifer. Int. J. Syst. Evol. Microbiol. 53: 823-827.

TERESA, L., GUGLIANDOLO, M.C., CACCAMO, D., PANICO, A., LAMA, L., GAMBACORTA, A. AND NICOLAUS, B. 2002. A halophilic thermotolerant Bacillus isolated from a marine hot spring able to produce a new exopolysaccharide. Biotechnology Letters. 24(7).

VASHISHTA, B.R. 1999. Botany (Part-1), Chand and Co. Ltd, New Delhi. pp.1544

WALTER, H. E., KUNSHAN, G., HONGXIA A., ZENGLING, M. AND VIRGINIA, E. V. 2006. Differential responses of Nostoc sphaeroides and Arthrospira platensis to solar ultraviolet radiation exposure. Journal of Applied Phycology. 18(1): 57-66.

Manuscript received on 28.8.09; Accepted on 29.12. 09

The Chittagong University Journal of Biological Sciences, Vol.4 ( 1 \& 2): Page no : 107-117 